\title{
Bilateral striatal necrosis caused by ADAR mutations in two siblings with dystonia and freckles-like skin changes that should be differentiated from Leigh syndrome
}

\author{
Dorota Piekutowska-Abramczuk ${ }^{1^{*}}$, Hanna Mierzewska ${ }^{2 *}$, Monika Bekiesińska-Figatowska ${ }^{3}$, Elżbieta Ciara ${ }^{1}$, \\ Joanna Trubicka ${ }^{1}$, Maciej Pronicki ${ }^{4}$, Dariusz Rokicki ${ }^{5}$, Małgorzata Rydzanicz ${ }^{6}$, Rafał Płoski ${ }^{6}$, Ewa Pronicka ${ }^{1,5}$ \\ ${ }^{1}$ Department of Medical Genetics, The Children's Memorial Health Institute, Warsaw, ${ }^{2}$ Department of Child and Adolescent Neurology, \\ Institute of Mother and Child, Warsaw, ${ }^{3}$ Department of Diagnostic Imaging, Institute of Mother and Child, Warsaw, ${ }^{4}$ Department \\ of Pathology, The Children's Memorial Health Institute, Warsaw, ${ }^{5}$ Department of Pediatrics, Nutrition and Metabolic Diseases, \\ The Children's Memorial Health Institute, Warsaw, ${ }^{6}$ Department of Medical Genetics, Warsaw Medical University, Warsaw, Poland \\ *These authors contributed equally to this work.
}

\begin{abstract}
Pathogenic molecular variants in the ADAR gene are a known cause of rare diseases, autosomal recessive AicardiGoutières syndrome type 6, severe infantile encephalopathy with intracranial calcifications and dominant dyschromatosis symmetrica hereditaria, demonstrated mainly in Asian adults. Recently, they have been also found in patients with nonsyndromic bilateral striatal necrosis accompanied by skin changes of the freckles-like type.

Here, we present Polish siblings with acute onset and slowly progressive extrapyramidal syndrome with preserved intellectual abilities and basal ganglia changes found in MRI. A Leigh syndrome was considered for a long time as the most frequent cause of such lesions in children. Finally, two molecular variants in non-mitochondria-related ADAR gene c.3202+1G>A (p.?) and c.577C>G (p.Pro193Ala) were revealed by whole exome sequencing.

We suggest that bilateral striatal necrosis should be always differentiated from LS to prevent the diagnosis delay. The striatal involvement accompanied by the presence of freckles-like skin changes should direct differential diagnosis to the ADAR gene mutations screening.
\end{abstract}

Key words: bilateral striatal necrosis, ADAR gene, whole exome sequencing, LS differentiation.

\section{Introduction}

Pathogenic molecular variants in the $A D A R$ gene [OMIM*146920] are a known cause of an AicardiGoutières syndrome type 6 (ASG6) [OMIM\#615010], an autosomal recessive severe infantile encephalo- pathy with intracranial calcifications [10] and a dyschromatosis symmetrica hereditaria (DSH) [OMIM \#127400], a rare dominant disease demonstrated mainly in Asian adults [8]. Recently, they have been also found in patients with nonsyndromic bilateral striatal necrosis (BSN) $[6,7]$ that is a frequent but 
nonspecific MRI feature observed in patients with an extrapyramidal syndrome, some of which had DSH [1]. Bilateral striatal necrosis was the most frequently reported in individuals with mitochondrial pathology presenting Leigh syndrome (LS) and MTATP6 mutation [3], thiamine metabolism dysfunction syndrome related to SLC25A19 pathogenic variants [11], and glutaric aciduria I with $G C D H$ variants [4], but rarely in Wilson's and Huntington diseases and other of inherited etiology as well as of certain acquired causes [1]. The prognosis for BSN is variable, with patients completely recovered and others developing severe dystonia or a more akinetic-rigid phenotype [7]. The ADAR gene (1q21.3) codes for specific deaminase which converses adenosine to inosine in double-stranded RNA influences glutamate receptor transcripts and acts as a suppressor of type I interferon signaling [10]. It is ubiquitously expressed in all tissues, but until today it has not been known why the signs of its dysfunction are limited to the nervous system and skin.

\section{Case study}

Here, we present two Polish siblings, the only children of unrelated parents, born after uneventful pregnancy and delivery. They both demonstrated acute onset with an episode of ataxia that occurred after a nonspecific infantile febrile infection followed by slowly progressive extrapyramidal syndrome (Table I). In infancy their development was mildly delayed, mainly in motor skills as they moved on their fours up to 2 and 3 years (Case 1 and 2 , respectively). When they started to walk independently, their movements were disturbed by an increased muscle tone with worsening during emotional stress. Tendency to retropulsion of the head, involuntary movements of facial muscles, athetotic movements of digits as well as dysarthric speech, dysphagia and frequent choking during eating were noticed. They both had small mild freckles-like skin changes on their faces and dorsal surfaces of hands. Both children were small for their age (weight and length < 2.5 SD, OCF < 3SD). Magnetic resonance imaging (MRI) examination (Fig. 1A-C) showed bilateral lesions in putamen on T2-weighted and FLAIR sequences that were suggestive for LS. Magnetic resonance spectroscopy (MRS) did not show any abnormalities. Muscle biopsy investigations did not reveal morphological changes and respiratory chain dysfunction.
During the following years, the clinical course of the disease was slowly progressive with the dominance of dystonic disorder, but intellectual ability was relatively preserved. At present (14 and 12 years), the siblings are wheel-chair bound and need full assistance with dressing and feeding.

Molecular screening for SURF1, SCO2, POLG, MTATP6, MTTL1, and MTTK mutations most frequently detected in Polish LS patients [9] was negative. Whole exome sequencing (WES) did not reveal deleterious mutations in genes responsible for known mitochondrial diseases (MD). Finally, two rare molecular variants (Fig. 1D, E) in non-mitochondria related ADAR gene (Ref Seq. NM_001111.4; NP_001102.2) included one novel splicing variant c.3202+1G>A (p.?) and a known recurrent substitution $c .577 C>$ G (p.Pro193Ala) were identified by thorough filtration of WES data and confirmed by Sanger sequencing in both siblings.

The study was approved by the Bioethical Commission of the CMHI.

\section{Discussion}

In the reported family the extended metabolic and mitochondrial investigations have been inconclusive for approximately 14 years. Our patients developed signs of the disease as a sequel of the infection, the finding pointed also by Livingston et al. [7]. Freckles-like skin changes on the face and the dorsal surface of hands were noticed in their medical documentation but were neglected in the differential diagnostics. Bilateral putaminal lesions found in MRI were not specific enough to establish a final diagnosis but together with the secondary abnormalities in lactate and alanine concentrations led us to consider for a long time a mitochondrial disease as the most frequent cause of such features in children. Our patients similar to those described in a cohort of children with nonsyndromic BSN [7] did not have any signs of calcification in the striatum or other localizations that were reported by Kumar et al. [5] in AGS brains.

It is worth noting that the $c .577 \mathrm{C}>\mathrm{G}$ (p.Pro193Ala) substitution was detected earlier in at least eleven AGS6 families $[7,10]$ and it was identified in the general population. The minor allele frequency (MAF) already recorded in ExAC database of 65000 exomes was 0.002142 (http://exac.broadinstitute.org), in 1000 Genomes was 0.0013 (http://browser.1000genomes.org), and in our in-house-made 400 exomes database it was evaluated as 0.0014 . It is located in 
Table I. Clinical and biochemical characteristics of the siblings with ADAR mutations

\begin{tabular}{|c|c|c|}
\hline Factor & Case 1 & Case 2 \\
\hline Gender & Male & Female \\
\hline Birth data (weight/length/OCF/Apgar points) & $3050 \mathrm{~g} / 53 \mathrm{~cm} / 36 \mathrm{~cm} / 9$ & $3400 \mathrm{~g} / 56 \mathrm{~cm} / 33 \mathrm{~cm} / 10$ \\
\hline \multicolumn{3}{|l|}{ Motility: } \\
\hline Sitting & $6 \mathrm{mo}$ & $7 \mathrm{mo}$ \\
\hline Start to walk & $10 \mathrm{mo}$ & $14 \mathrm{mo}$ \\
\hline Stop to walk independently & 4 yrs & $>4 \mathrm{yrs}$ \\
\hline First symptoms & $12 \mathrm{mo}$ & $8 \mathrm{mo}$ \\
\hline Extrapyramidal signs & $\begin{array}{l}3 \text { yrs: dystonia, elevated tendon } \\
\text { reflexes, striatal great toe }\end{array}$ & $\begin{array}{c}4 \text { yrs: axial and limbs hypotonia, } \\
\text { dystonic hypertonia, elevated } \\
\text { and polyclonal reflexes }\end{array}$ \\
\hline \multicolumn{3}{|l|}{ Neurologic examination: } \\
\hline EEG & Normal & Normal \\
\hline EMG & Normal & Normal \\
\hline Fundoscopy & Normal & Normal \\
\hline Nerve conduction & $\begin{array}{l}\text { Sensory-motor neuropathy } \\
\text { of axonal type }\end{array}$ & $\begin{array}{l}\text { Sensory-motor neuropathy } \\
\text { of axonal type }\end{array}$ \\
\hline MRI & Symmetrical changes in putamen & Symmetrical changes in putamen \\
\hline MRS & Normal & Normal \\
\hline Leiter International Performance Scale* & 100 & 112 \\
\hline \multicolumn{3}{|l|}{ CSF examination: } \\
\hline Pleocytosis & $1 / \mathrm{ml}$ & \\
\hline Protein content (ref. 200-450 mg/dl) & $239 \mathrm{mg} / \mathrm{dl}$ & \\
\hline Glucose (ref. $45-80$ mg/dl) & $50 \mathrm{mg} / \mathrm{dl}$ & \\
\hline Lactate $($ ref. $<2.2 \mathrm{mmol} / \mathrm{l})$ & $1.1 \mathrm{mmol} / \mathrm{l}$ & 1.57 \\
\hline Alanine (ref. 65 umol/l) & $98.8 \mu \mathrm{mol} / \mathrm{l}$ & 51.9 \\
\hline Threonine & $67.4 \mu \mathrm{mol} / \mathrm{l}$ & \\
\hline \multicolumn{3}{|l|}{ Laboratory tests for IEM: } \\
\hline Plasma lactate (ref. < $2 \mathrm{mmol} / \mathrm{l})$ & $3.08,2.42$ & 3.01 \\
\hline Plasma alanine (ref. < 450 umol/l) & $706.8 \mu \mathrm{mol} / \mathrm{l}$ & \\
\hline Threonine & $170.9 \mu \mathrm{mol} / \mathrm{l}$ & \\
\hline $\begin{array}{l}\text { Urine biopterin concentration } \\
\text { (based on creatinine (C) conc.) }\end{array}$ & $\begin{array}{c}4594 \mathrm{nmol} / \mathrm{l} \\
(2.7 \mathrm{nmol} \mathrm{B} / \mathrm{\mu mol} / \mathrm{C})\end{array}$ & \\
\hline $\begin{array}{l}\text { Urine neopterin concentration } \\
\text { (based on creatinine (C) conc.) }\end{array}$ & $\begin{array}{c}2027 \mathrm{nmol} / / \\
(1.2 \mathrm{nmol} / / \mu \mathrm{mol} / \mathrm{C})\end{array}$ & \\
\hline Muscle biopsy investigations: & & NA \\
\hline Morphology & No changes & \\
\hline OXPHOS function & Normal & \\
\hline Amount of E1-alfa subunit of PDHC & $79.5 \%$ of ref. & \\
\hline $\begin{array}{l}\text { Molecular screening for SURF1, SCO2, } \\
\text { MTATP6, POLG, MTTL1, MTTK common } \\
\text { mutations }\end{array}$ & Negative & NA \\
\hline
\end{tabular}

*Leiter RG. Instruction Manual for the Leiter International Performance Scale. Stoelting Co., Wood Dale 1979

** .845 846delCT, c.312 321delinsAT (SURF1), c.418G>A (SCO2), m.8993T>G, m.8993T>C (MTATP6); c.1399G >A, c.2243G>C, c.2542G>A (POLG); m.3243A>G (MTTL1), m.8344A>G (MTTK)

mo - months, yrs - years, EEG - electroencephalography, EMG - electromyography, MRI - magnetic resonance imaging, MRS - magnetic resonance spectrometry, IEM - inborn errors of metabolism, OXPHOS-oxidative phosphorylation system, PDHC-pyruvate dehydrogenase complex, NA - not analyzed, ref. - control values 

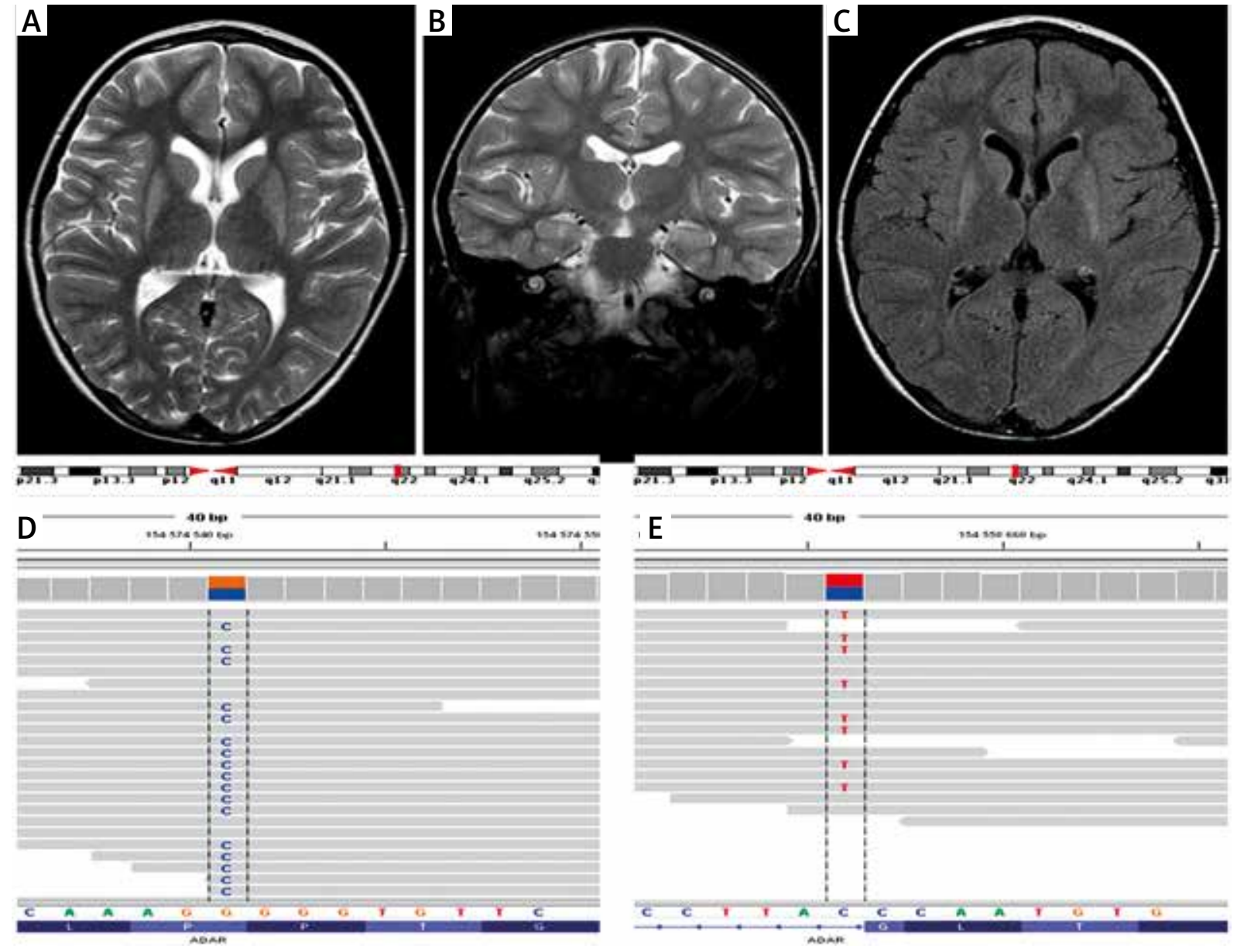

Fig. 1. Magnetic resonance imaging and molecular findings revealed in Case 1. A-C) Bilateral involvement of the putamen with hyperintense signal on T2-weighted images: axial plane, coronal plane, and on FLAIR sequence, respectively. D, E) Integrative Genomics Viewer picture of identified ADAR causative variants c. $577 C>G$ and c.3202+1G>A. The depth of coverage across the variants was $8 / 16$ and $18 / 37$, respectively

the highly evolutionary conserved z-alpha adenosine deaminase domain and results in removing important atomic interactions between protein and DNA/ RNA [2].

\section{Conclusions}

In conclusion, we suggest that the disease should be always differentiated from LS to prevent diagnosis delay. We would like to underline that presence of specific MRI features of bilateral striatal necrosis and freckles-like skin changes should direct differential diagnosis to the $A D A R$ mutations screening.

\section{Acknowledgements}

We thank the family for participation in the study. The study was partly supported by the $\mathrm{CMHI}$ project no. S136/13 and NSC grant no. 2012/05/B/ NZ2/01627.

\section{Disclosure}

Authors report no conflict of interest.

\section{References}

1. Bekiesińska-Figatowska M, Mierzewska H, Jurkiewicz E. Basal ganglia lesion in children and adults. Eur J Radiol 2013; 82: 5-30.

2. Crow YJ, Chase DS, Lowenstein Schmidt J, Szynkiewicz M, Forte GM, Gornall HL, Oojageer A, Anderson B, Pizzino A, Helman G, Abdel-Hamid MS, Abdel-Salam GM, Ackroyd S, Aeby A, Agosta G, Albin C, Allon-Shalev S, Arellano M, Ariaudo G, Aswani V, Babul-Hirji R, Baildam EM, Bahi-Buisson N, Bailey KM, Barnerias C, Barth M, Battini R, Beresford MW, Bernard G, Bianchi M, Billette de Villemeur T, Blair EM, Bloom M, Burlina AB, Carpanelli ML, Carvalho DR, Castro-Gago M, Cavallini A, Cereda C, 
Chandler KE, Chitayat DA, Collins AE, Sierra Corcoles C, Cordeiro NJ, Crichiutti G, Dabydeen L, Dale RC, D’Arrigo S, De Goede CG, De Laet C, De Waele LM, Denzler I, Desguerre I, Devriendt K, Di Rocco M, Fahey MC, Fazzi E, Ferrie CD, Figueiredo A, Gener B, Goizet C, Gowrinathan NR, Gowrishankar K, Hanrahan D, Isidor B, Kara B, Khan N, King MD, Kirk EP, Kumar R, Lagae L, Landrieu P, Lauffer H, Laugel V, La Piana R, Lim MJ, Lin JP, Linnankivi T, Mackay MT, Marom DR, Marques Lourenço C, McKee SA, Moroni I, Morton JE, Moutard ML, Murray K, Nabbout R, Nampoothiri S, Nunez-Enamorado N, Oades PJ, Olivieri I, Ostergaard JR, PérezDueñas B, Prendiville JS, Ramesh V, Rasmussen M, Régal L, Ricci F, Rio M, Rodriguez D, Roubertie A, Salvatici E, Segers KA, Sinha GP, Soler D, Spiegel R, Stödberg TI, Straussberg R, Swoboda KJ, Suri M, Tacke U, Tan TY, te Water Naude J, Wee Teik K, Thomas MM, Till M, Tonduti D, Valente EM, Van Coster RN, van der Knaap MS, Vassallo G, Vijzelaar R, Vogt J, Wallace GB, Wassmer E, Webb HJ, Whitehouse WP, Whitney RN, Zaki MS, Zuberi SM, Livingston JH, Rozenberg F, Lebon P, Vanderver A, Orcesi S, Rice GI. Characterization of human disease phenotypes associated with mutations in TREX1, RNASEH2A, RNASEH2B, RNASEH2C, SAMHD1, ADAR, and IFIH1. Am J Med Genet A 2015; 167A: 296-312.

3. De Meirleir L, Seneca S, Lissens W, Schoentjes E, Desprechins B. Bilateral striatal necrosis with a novel point mutation in the mitochondrial ATPase 6 gene. Pediatr Neurol 1995; 13: 242-246.

4. Herskovitz M, Goldsher D, Sela BA, Mandel H. Subependymal mass lesions and peripheral polyneuropathy in adult-onset glutaric aciduria type I. Neurology 2013; 81: 849-850.

5. Kumar D, Rittey C, Cameron AH, Variend S. Recognizable inherited syndrome of progressive central nervous system degeneration and generalized intracranial calcification with overlapping phenotype of the syndrome of Aicardi and Goutie'res. Am J Med Gen 1998; 75: 508-515.

6. La Piana R, Uggetti C, Olivieri I, Tonduti D, Balottin U, Fazzi E, Orcesi S. Bilateral striatal necrosis in two subjects with Aicardi-Goutières syndrome due to mutations in ADAR1 (AGS6). Am J Med Genet A 2014; 164A: 815-819.

7. Livingston JH, Lin JP, Dale RC, Gill D, Brogan P, Munnich A, Kurian MA, Gonzalez-Martinez V, De Goede CG, Falconer A, Forte G, Jenkinson EM, Kasher PR, Szynkiewicz M, Rice GI, Crow YJ. A type I interferon signature identifies bilateral striatal necrosis due to mutations in ADAR1. J Med Genet 2014; 51: 76-82.

8. Miyamura Y, Suzuki T, Kono M, Inagaki K, Ito S, Suzuki N, Tomita Y. Mutations of the RNA-specific adenosine deaminase gene (DSRAD) are involved in dyschromatosis symmetrica hereditaria. Am J Hum Genet 2003; 73: 693-699.

9. Piekutowska-Abramczuk D. The molecular background of Leigh syndrome. Neurol Neurochir Pol 2008; 42: 238-250.

10. Rice Gl, Kasher PR, Forte GM Mannion NM, Greenwood SM, Szynkiewicz M, Dickerson JE, Bhaskar SS, Zampini M, Briggs TA, Jenkinson EM, Bacino CA, Battini R, Bertini E, Brogan PA, Brueton LA, Carpanelli M, De Laet C, de Lonlay P, del Toro M, Desguerre I, Fazzi E, Garcia-Cazorla A, Heiberg A, Kawaguchi M, Kumar R, Lin JP, Lourenco CM, Male AM, Marques W Jr, Mignot C, Olivieri I, Orcesi S, Prabhakar P, Rasmussen M, Robinson RA, Rozenberg F, Schmidt JL, Steindl K, Tan TY, van der Merwe WG, Vanderver A, Vassallo G, Wakeling EL, Wassmer E, Whittaker E
Livingston JH, Lebon P, Suzuki T, McLaughlin PJ, Keegan LP, O'Connell MA, Lovell SC, Crow YJ. Mutations in ADAR1 cause Aicardi-Goutières syndrome associated with a type I interferon signature. Nat Genet 2012; 44: 1243-1248.

11. Spiegel R, Shaag A, Edvardson S, Mandel H, Stepensky P, Shalev SA, Horovitz Y, Pines O, Elpeleg O. SLC25A19 mutation as a cause of neuropathy and bilateral striatal necrosis. Ann Neurol 2009; 66: 419-424. 